\title{
PENGARUH TENOR, UKURAN, DAN SPESIALISASI KANTOR AKUNTAN PUBLIK TERHADAP KUALITAS AUDIT
}

\author{
Tjun Tjun \\ Program Studi Magister Akuntansi Fakultas Ekonomi \\ Universitas Tarumanagara, Jakarta \\ Email: tjun94tjun@gmail.com
}

\begin{abstract}
This study aims to examine how far Public Accounting Firm tenure, Public Accounting Firm size and Public Accounting Firm specialization influenced audit quality partially and simultaneously. This study was conducted using manufacturing companies on Indonesian Stock Exhange during 2012-2016 period as samples. Data analysis was conducted using multiple regression models. The result proves that Public Accounting Firm tenure, Public Accounting Firm size and Public Accounting Firm specialization affect audit quality simultaneously. This study also proves that Public Accounting Firm tenure and Public Accounting Firm specialization affect audit quality partially, while Public Accounting Firm size does not affect audit quality.
\end{abstract}

Keywords: Tenor of the Public Accountant Office, Size of the Public Accounting Firm, Specialization of the Office of Public Accountants, Audit Quality.

\begin{abstract}
ABSTRAK
Penelitian ini bertujuan untuk menguji sejauh mana tenor Kantor Akuntan Publik, ukuran Kantor Akuntan Publik, dan spesialisasi Kantor Akuntan Publik mempengaruhi kualitas audit baik secara parsial dan simultan. Penelitian ini dilakukan menggunakan sampel perusahaan manufaktur di Bursa Efek Indonesia pada periode 2012-2016. Analisis data dilakukan dengan model regresi berganda. Hasil penelitian ini membuktikan bahwa tenor Kantor Akuntan Publik, ukuran Kantor Akuntan Publik, dan spesialisasi Kantor Akuntan Publik secara simultan berpengaruh terhadap kualitas audit. Penelitian ini membuktikan bahwa tenor Kantor Akuntan Publik dan spesialisasi Kantor Akuntan secara parsial berpengaruh terhadap kualitas audit, sedangkan ukuran Kantor Akuntan Publik tidak berpengaruh terhadap kualitas audit.
\end{abstract}

Kata Kunci: tenor kantor akuntan publik, ukuran kantor akuntan publik, spesialisasi kantor akuntan publik dan kualitas audit.

\section{PENDAHULUAN}

\section{Latar Belakang}

Peranan audit atas laporan keuangan sangat penting dalam perekonomian saat ini, terutama kaitannya dengan perkembangan pasar modal dan pasar uang. Terjadinya beberapa skandal akuntansi, misalnya terkait kasus Enron di Amerika Serikat, menimbulkan pertanyaan pada pihak mengenai keakuratan laporan keuangan yang diaudit kantor akuntan publik. Pertanyaan lain yang timbul adalah apakah terdapat faktor-faktor yang dapat menjelaskan kualitas dari suatu audit yang dilakukan.

Lamanya pemberian jasa kepada perusahan oleh kantor akuntan publik ditakutkan akan mengurangi independensi, objektivitas dan skeptisisme profesional auditor sehingga manajemen laba perusahaan akan meningkat (Nata, 2010). Di lain pihak, pemahaman atas bisnis perusahaan yang lebih baik yang diperoleh melalui pemberian jasa yang panjang akan lebih memampukan auditor untuk mendeteksi manajemen laba yang dilakukan perusahaan (Nata, 2010).

Dalam “A Framework for Audit Quality" yang dikeluarkan IAASB (2013), ketua IAASB mengatakan bahwa istilah "kualitas audit" sering digunakan dalam perdebatan antara stakeholder, komunikasi dengan regulator, pembuat standar, kantor akuntan publik dan lain-lain. Kualitas audit merupakan subyek yang kompleks dan tidak terdapat definisi atau analisis yang mendapat pengakuan universal. Dari sekian banyak faktor, salah satu faktor yang terkait dengan kualitas audit adalah ukuran kantor akuntan publik, yang merepresentasikan independensi (karena terdapat portofolio klien yang besar) dan 
pemanfaatan atas teknologi informasi. Selain ukuran kantor akuntan publik, spesialisasi kantor akuntan publik juga akan mempengaruhi kualitas audit terkait dengan kompetensi yang dimiliki auditor sebagai spesialis industri.

Terkait hubungan antara ukuran kantor akuntan publik dan kualitas audit, masyarakat memandang bahwa jasa audit yang diberikan auditor Big 4 lebih berkualitas daripada Non-Big 4. Namun atas beberapa skandal akuntansi yang melibatkan auditor Big 4 seperti kasus Enron yang diaudit Arthur Andersen atau Satyam yang diaudit oleh PwC, atau kasus Lehman Brothers dan Toshiba yang diaudit EY, menimbulkan pertanyaan mengenai kualitas audit yang diberikan auditor Big 4 .

Berdasarkan diskusi mengenai Indikator Kualitas Audit yang dikeluarkan Public Company Accounting Oversight Board (PCAOB), salah satu indikator kualitas audit pada input operasional keahlian dan pemahaman industri. Keahlian dan pemahaman industri ini mengukur pengetahuan personel audit dalam industri tertentu. Hal ini dapat diukur melalui, diantaranya, jumlah tahun-tahun pengalaman yang dicurahkan pada industri tertentu oleh professional audit. Riset akademis terkait pengalaman industri auditor ditemukan berhubungan positif dengan kualitas audit.

Penelitian ini bertujuan untuk memberikan bukti empiris di Indonesia mengenai pengaruh dari lamanya pemberian jasa audit yang diberikan kantor akuntan publik (tenure), ukuran dan spesialisasi kantor akuntan publik terhadap kualitas audit untuk perusahaan manufaktur yang telah mencatatkan sahamnya di Bursa Efek Indonesia.

\section{Kajian Teori}

Dalam teori keagenan dari Jensen dan Meckling (1976) dijelaskan mengenai konsep biaya keagenan dan memperlihatkan hubungannya dengan masalah "separation and control".

Hubungan keagenan adalah kontrak antara principal yang meminta jasa dari agen untuk melakukan pekerjaan untuk kepentingan principal dengan mendelegasikan beberapa otoritas pengambilan keputusan kepada agen. Secara umum adalah tidak mungkin bagi principal atau agen dengan biaya nihil dimana agen akan membuat keputusan optimal dari sisi pandangan prinsipal. Dengan demikian hubungan keagenan itu akan menimbulkan biaya monitoring dan bonding, serta residual loss yang dikenal dengan biaya keagenan.

Teori keagenan ini juga menjelaskan mengapa auditor independen akan diminta manajemen untuk memberikan pernyataan mengenai keakuratan dan kebenaran dari laporan keuangan.

Terdapat banyak definisi mengenai kualitas audit, di antaranya dari tingkat compliance dengan standar akuntansi dan tingkat asuran dari laporan keuangan.

Sesuai dengan "A Framework for Audit Quality" yang diterbitkan International Auditing and Assurance Standards Board (IAASB), auditor bertanggungjawab atas kualitas audit dan memastikan bahwa kualitas audit dihasilkan secara konsisten. Kualitas audit dapat tercapai apabila opini atas laporan keuangan dapat diandalkan karena didasarkan pada bukti audit yang tepat yang diperoleh tim perikatan yang menunjukkan nilai, etika, tingkah laku yang tepat, memiliki pengetahuan dan pengalaman yang memadai dan memiliki waktu yang cukup yang dialokasikan untuk melakukan pekerjaan audit, mengaplikasian proses audit yang ketat dan prosedur quality control dan berinteraksi dengan tepat berbagai stakeholder.

Menurut DeAngelo (1981), kualitas audit tidak terlepas dari audit ukuran kantor akuntan publik, meskipun auditor memiliki kapabilitas teknologi yang sama. Semakin besar auditor, yang diukur dari jumlah klien, semakin kecil insentif bagi auditor untuk bersikap oportunis, dan semakin tinggi kualitas audit yang ditampilkan. 
Berdasarkan penelitian Nata (2010), dengan audit firm tenure yang lebih panjang, manajemen laba akan menurun, karena pemahaman atas bisnis perusahaan yang lebih baik yang dimiliki kantor akuntan publik.

Berdasarkan penelitian Chen et al (2004) atas perusahaan-perusahaan yang tercatat di bursa efek di Taiwan, tidak terdapat bukti bahwa kualitas laba menurun sejalan dengan audit firm tenure.

Berdasarkan penelitian Herusetya (2009), tidak terdapat bukti bahwa terdapat perbedaan kualitas laba antara perusahaan-perusahaan yang diaudit auditor Big 4 dan auditor non-Big 4.

Dalam penelitian Wibowo dan Hilda (2009), ukuran kantor akuntan publik (KAP) berpengaruh terhadap kualitas audit, konsisten dengan pendapat DeAngelo (1981), di mana semakin besar ukuran KAP maka akan semakin baik kualitas audit yang dihasilkan.

Berdasarkan penelitian Balsam (2003), klien-klien yang diaudit auditor spesialis memiliki discretionary accrual yang lebih rendah, dengan kata lain, klien-klien yang dimiliki spesialis industri memiliki kualitas laba yang lebih tinggi dari klien-klien yang bukan spesialis industri.

Berdasarkan penelitian Fitriany et al (2015), spesialisasi kantor akuntan publik memiliki pengaruh positif terhadap kualitas audit.

Berdasarkan penelitian Herusetya (2009), tidak terdapat bukti dimana terdapat perbedaan kualitas laba dari perusahaan-perusahaan yang diaudit oleh kantor akuntan publik dengan spesialisasi industri dengan yang tidak memiliki spesialisasi industri.

Dalam penelitian Meza (2010) mengenai kaitan antara auditor spesialisasi industri dan kualitas audit, ditemukan bahwa tidak terdapat $\mathrm{p}$ erbedaan signifikan antara dua group auditor tersebut.

Variabel-variabel kontrol yang digunakan dalam penelitian ini adalah ukuran perusahaan (Size), pertumbuhan perusahaan (Growth), leverage (Lev), kerugian (loss) dan arus kas operasi $(C F O)$.

Dalam Lobo et al (2006), perusahaan besar mendapat perhatian dari analis dan investor keuangan karena perusahaan besar memiliki pengaruh yang lebih terhadap pasar modal karena besarnya kapitalisasi pasar mereka. Karenanya, perusahaan besar kurang memiliki fleksibilitas dan insentif yang kecil untuk salah saji penghasilan mereka. Sebaliknya, perusahaan besar memiliki kesempatan yang lebih besar untuk melakukan salah saji karena kompleksitas dari operasi mereka dan kesulitan dari pemakai eksternal untuk mendeteksi salah saji tersebut.

Berdasarkan penelitian yang dilakukan Siregar (2005), ukuran perusahaan berpengaruh secara signifikan negatif terhadap besarnya akrual diskresioner perusahaan. Sebaliknya, dalam penelitian Lobo et al (2006), ukuran perusahaan berpengaruh secara signifikan positif terhadap akrual diskresioner perusahaan.

Dengan demikian, ukuran perusahaan dapat berpengaruh positif maupun negatif terhadap kualitas audit. Variabel ini diukur dengan logaritma natural dari total aset.

Dalam penelitian Maria (2016), pertumbuhan penjualan digunakan karena akrual berkorelasi tinggi dengan pertumbuhan perusahaan.

Menurun Cameran (2014), leverage (diukur dengan rasio dari total liabilitas dibandingkan dengan total aset pada tahun t) digunakan sebagai proksi untuk kemungkinan terjadinya pelanggaran atas kovenan utang yang mungkin menciptakan insentif untuk meningkatkan laba melalui abnormal accrual yang lebih tinggi, karena itu diperkirakan adanya koefisien yang positif.

Kerugian mencerminkan kondisi keuangan perusahaan dimana perusahaan yang mengalami kerugian mempunyai insentif yang lebih besar untuk melakukan manajemen 
laba. Manajemen laba yang semakin besar menunjukkan kualitas audit yang kurang baik (Fitriany, 2015).

Arus kas operasi digunakan karena terdapat hubungan yang negatif antara akrual dan arus kas (Dechow, 1994).

\section{Rumusan Masalah}

Berdasarkan identifikasi masalah yang telah dilakukan pembatasan ruang lingkup di atas, maka perumusan masalahnya adalah:

1. Apakah lamanya pemberian jasa audit yang diberikan kantor akuntan publik (tenor) berpengaruh terhadap kualitas audit?

2. Apakah ukuran kantor akuntan publik berpengaruh terhadap kualitas audit?

3. Apakah spesialisasi kantor akuntan publik berpengaruh terhadap kualitas audit?

Tujuan dari penelitian ini adalah untuk mendapatkan bukti empiris dan menganalisis mengenai hal-hal berikut:

1. Pengaruh lamanya pemberian jasa audit yang diberikan kantor akuntan publik (tenor) terhadap kualitas audit.

2. Pengaruh ukuran kantor akuntan publik terhadap kualitas audit.

3. Pengaruh spesialisasi kantor akuntan publik terhadap kualitas audit.

\section{METODE PENELITIAN}

Objek penelitian dalam penelitian ini adalah pengaruh tenor kantor akuntan publik $\left(\mathrm{X}_{1}\right)$, ukuran kantor akuntan publik $\left(\mathrm{X}_{2}\right)$, dan spesialisasi kantor akuntan publik $\left(\mathrm{X}_{3}\right)$ terhadap kualitas audit $(\mathrm{Y})$. Variabel independen pada penelitian ini adalah tenor kantor akuntan publik, ukuran kantor akuntan publik, dan spesialisasi kantor akuntan publik. Variabel kontrol pada penelitin ini adalah ukuran perusahaan, pertumbuhan perusahaan, leverage, kerugian dan arus kas operasi. Sedangkan sebagai variabel dependen penelitian ini adalah kualitas audit (Y).

Penelitian ini dilakukan pada perusahaan manufaktur yang terdaftar di Bursa Efek Indonesia periode 2012-2016. Populasinya adalah semua perusahaan yang terdaftar di BEI yang bergerak pada industri manufaktur, yang meliputi Industri Dasar dan Kimia, Aneka Industri dan Industri Barang Konsumsi. Sampel perusahaan dipilih dari keseluruhan populasi perusahaan publik yang bergerak pada industri manufaktur di BEI dan berdasarkan ketersediaan data untuk menghitung variabel-variabel yang dijelaskan sebelumnya.

Teknik pengambilan sampel dalam penelitian ini menggunakan metode purposive sampling method. Teknik ini mengambil sampel dari tempat tertentu (dalam hal ini Bursa Efek Indonesia) dan menggunakan kriteria untuk tujuan tertentu yang dianggap potensial dalam penelitian ini.

Teknik ini juga termasuk dalam jenis teknik pengambilan sampel secara nonprobabilitas yaitu peneliti menentukan sendiri sampel perusahaan-perusahaan berdasarkan kriteria sebagai berikut :

1. Perusahaan-perusahaan manufaktur yang terdaftar di Bursa Efek Indonesia (BEI) dari

tahun 2012 sampai dengan tahun 2016.

2. Perusahaan-perusahaan manufaktur yang memiliki laporan keuangan yang terpublikasi

dan telah diaudit dari tahun 2012 sampai dengan tahun 2016. 
Berdasarkan data Fact Book 2016 Bursa Efek Indonesia (BEI) menunjukkan terdapat perusahaan manufaktur (terdiri dari industri dasar dan kimia, industri lainnya dan industri consumer good, sebanyak 145 perusahaan. Jumlah sampel penelitian selama tahun 2012 sampai tahun 2016 perusahaan-perusahaan manufaktur sebanyak 111 perusahaan.

Penelitian ini menggunakan sumber data sekunder berupa laporan keuangan dan laporan auditor independen. Data yang digunakan dalam penelitian ini bersumber dari akses internet melalui www.idx.co.id.

Kualitas audit sulit diukur karena jumlah asurans yang diberikan auditor tidak dapat diobservasi. Salah satu cara untuk mengukur kualitas audit adalah dengan melihat output dari suatu proses audit, seperti opini kelangsungan usaha dan kualitas pelaporan keuangan. Proksi berdasarkan output ini dapat mengukur tingkat kualitas audit yang diberikan. Karena itu penelitian untuk faktor penawaran sering memakai proksi berdasarkan output ini. Alternatif lain untuk mengukur kualitas audit dengan melihat input audit seperti auditor size dan fee audit. Karena itu penelitian untuk faktor permintaan sering memakai proksi berdasarkan input yang dapat diobservasi ini.

Dalam penelitian ini, kualitas audit akan diukur dengan memakai proksi output, yakni Discretionary Accrual, seperti yang dipakai Davis et al (2010). Total Akrual (TA) dihitung sebagai berikut:

$$
\mathrm{TA}_{\mathrm{it}}=\Delta \mathrm{CA}_{\mathrm{it}}-\Delta \mathrm{CL}_{\mathrm{it}}-\Delta \mathrm{CASH}_{\mathrm{it}}+\Delta \mathrm{CPLTD}_{\mathrm{it}}-\mathrm{DEPN}_{\mathrm{it}}
$$

Dimana:

$\triangle \mathrm{CA}_{\mathrm{it}}=$ perubahan aset lancar untuk perusahaan i pada tahun $\mathrm{t}$

$\triangle \mathrm{CL}_{\mathrm{it}}=$ perubahan kewajiban lancar untuk perusahaan i pada tahun $\mathrm{t}$

$\triangle \mathrm{CASH}_{\mathrm{it}}=$ perubahan kas dan setara kas untuk perusahaan i pada tahun $\mathrm{t}$

$\triangle$ CPLTD $_{\mathrm{it}}=$ perubahan utang jangka panjang jatuh tempo dalam satu tahun untuk perusahaan i pada tahun $\mathrm{t}$

$\mathrm{DEPN}_{\mathrm{it}}=$ beban penyusutan dan amortisasi untuk perusahaan i pada tahun $\mathrm{t}$

Discretionary Accrual (DA) yang merupakan komponen dari Total Akrual diestimasi dari model Jones (1991):

$$
\begin{aligned}
& \mathrm{DA}_{\mathrm{it}} / \mathrm{A}_{\mathrm{i}, \mathrm{t}-1}=\mathrm{TA}_{\mathrm{it}} / \mathrm{A}_{\mathrm{i}, \mathrm{t}-1}-\left[\beta_{\mathrm{o}}\left(1 / \mathrm{A}_{\mathrm{i}, \mathrm{t}-1}\right)+\beta_{1}\left(\mathrm{PPE}_{\mathrm{it}} / \mathrm{A}_{\mathrm{i}, \mathrm{t}-1}\right)+\beta_{2}\left(\Delta \mathrm{REV} \mathrm{V}_{\mathrm{it}} / \mathrm{A}_{\mathrm{i}, \mathrm{t}-1}\right)\right] \\
& \mathrm{DA}_{\mathrm{it}}=\text { discretionary Accrual untuk perusahaan i pada tahun } \mathrm{t} \\
& \mathrm{A}_{\mathrm{i}, \mathrm{t}-\mathrm{1}}=\text { total aset untuk perusahaan i pada tahun } \mathrm{t}-1 \\
& \mathrm{PPE}_{\mathrm{it}}=\text { properti dan peralatan bruto untuk perusahaan i pada tahun } \mathrm{t} \\
& \triangle \mathrm{REV}_{\mathrm{it}}=\text { perubahan pendapatan tahunan untuk perusahaan } \mathrm{i} \text { pada tahun } \mathrm{t}
\end{aligned}
$$

dimana beta 0,1 dan 2 diperoleh dari estimasi cross-sectional, industri, dan tahun tertentu, dengan persamaan sebagai berikut:

$$
\mathrm{TA}_{\mathrm{it}} / \mathrm{A}_{\mathrm{i}, \mathrm{t}-1}=\beta_{\mathrm{o}}\left(1 / \mathrm{A}_{\mathrm{i}, \mathrm{t}-1}\right)+\beta_{1}\left(\mathrm{PPE}_{\mathrm{it}} / \mathrm{A}_{\mathrm{i}, \mathrm{t}-1}\right)+\beta_{2}\left(\Delta \mathrm{REV}_{\mathrm{it}} / \mathrm{A}_{\mathrm{i}, \mathrm{t}-1}\right)+\mathrm{e}_{\mathrm{it}}
$$

Tenor Kantor Akuntan Publik adalah lamanya tahun jasa audit yang diberikan kantor akuntan publik.

Ukuran kantor akuntan publik adalah ukuran besarnya kantor akuntan publik, merupakan dummy variable, dimana pada penelitian ini, kantor akuntan publik yang 
memiliki pendapatan di atas Rp 100 miliar termasuk golongan kantor akuntan publik ukuran besar. Jika kantor akuntan publik memiliki pendapatan di atas Rp 100 miliar, maka mendapat angka 1. Jika memiliki pendapatan di bawah Rp 100 miliar, mendapat angka 0 .

Spesialisasi kantor akuntan publik maksudnya kantor akuntan publik memiliki pengalaman yang banyak dalam mengaudit perusahaan-perusahaan dalam industri yang sama. Dengan banyaknya pengalaman audit tersebut akan meningkatkan kemampuan dari kantor akuntan publik dalam mendeteksi kecurangan atau fraud dalam laporan keuangan yang pada akhirnya tercapai kualitas audit yang tinggi.

Karena spesialisasi kantor akuntan publik tidak dapat secara langsung diobservasi, dalam penelitian terdahulu menggunakan beberapa proksi untuk mengukur spesialisasi industri (Balsam, 2003), diantaranya auditor dengan jumlah terbanyak dalam industri, jumlah klien yang dimiliki (market share), jumlah klien yang diaudit kantor akuntan publik, supplier terbesar dalam industri, dominasi industri, dan berdasarkan market share berdasarkan besarnya penjualan klien.

Dalam penelitian ini, menggunakan proksi market share di atas $10 \%$ berdasarkan besarnya penjualan dalam industri manufaktur yang listed di Bursa Efek Indonesia sebagai spesialisasi kantor akuntan publik.

Data dalam penelitian ini dianalisis dengan menggunakan metode Multiple Regression Analysis dengan bantuan alat uji SPSS (Statistical Product and Service Solution) Statistics 22.

Model regresi yang baik harus memenuhi empat uji asumsi klasik, yang meliputi: uji normalitas, uji heteroskedastisitas, uji multikolinieritas dan uji autokorelasi.

Dalam penelitian ini menggunakan model regresi berganda untuk menganalisis data responden, sebagai berikut:

keterangan:

$\mathrm{Y}$

$$
\mathrm{Y}=\beta_{0}+\beta_{1} X_{1}+\beta_{2} X_{2}+\beta_{3} X_{3}+\varepsilon
$$

$\begin{array}{ll}X_{1} & \text { Tenor Kantor Akuntan Publik } \\ X_{2} & \text { Ukuran Kantor Akuntan Publik } \\ X_{3} & \text { Spesialisasi Kantor Akuntan Publik } \\ \beta_{1-} \beta_{3} & \text { Koefisien variabel } \\ \varepsilon & \text { error }\end{array}$

Dalam model regresi berganda perlu dilakukan uji $\mathrm{F}$ (pengujian simultan) dan uji $\mathrm{t}$ (pengujian parsial), termasuk pengujian koefisien determinasi.

\section{HASIL DAN PEMBAHASAN}

Terdapat 111 perusahaan yang dijadikan kriteria dengan tiga variabel independen. Semua data penelitian yang telah diperoleh kemudian diolah dengan menggunakan Microsoft Excel, selanjutnya dilakukan pengujian statistik deskriptif, pengujian normalitas, pengujian asumsi klasik, pengujian korelasi sederhana dan pengujian regresi berganda yang dilakukan dengan menggunakan program Statistical Products and Service Solution 22 (SPSS 22). Prosedur dimulai dengan memasukkan variabel penelitian ke program SPSS 22, kemudian diolah sehingga menghasilkan output yang sesuai dengan metode analisis data yang telah ditentukan. Sebelum melakukan pengujian, outliers dan kualitas audit yang bernilai negatif telah dikeluarkan dari data yang ada, sehingga jumlah sampel menjadi sebanyak 485 data. 
Pengolahan variabel penelitian dengan program SPSS 22 dilakukan melalui model I dan II. Variabel-variabel kontrol yang meliputi ukuran perusahaan, pertumbuhan perusahaan, leverage, kerugian dan arus kas operasi perusahaa dimasukkan sebagai model I. Kemudian, untuk variabel-variabel independen yang meliputi tenor, ukuran dan spesialisasi kantor akuntan publik dimasukkan sebagai model II.

Statistik deskriptif dari variabel-variabel penelitian tersebut tersebut dapat dilihat pada tabel berikut:

Tabel 1 Hasil Pengujian Statistik Deskriptif

(Sumber: hasil olah data)

Descriptive Statistics

\begin{tabular}{|l|r|r|r|r|r|}
\hline & $\mathrm{N}$ & $\begin{array}{r}\text { Minimu } \\
\mathrm{m}\end{array}$ & $\begin{array}{c}\text { Maximu } \\
\mathrm{m}\end{array}$ & \multicolumn{1}{c|}{$\begin{array}{c}\text { Std. } \\
\text { Dean }\end{array}$} \\
\hline Kualitas Audit & 485 & .00 & .73 & .2870 & .17328 \\
Tenor KAP & 485 & 1.00 & 5.00 & 2.5505 & 1.37871 \\
Ukuran KAP & 485 & .00 & 1.00 & .4660 & .49936 \\
Spesialisasi & 485 & .00 & 1.00 & .3794 & .48573 \\
KAP & & & & & \\
Valid N & 485 & & & & \\
(listwise) & & & & & \\
\hline
\end{tabular}

Berdasarkan tabel 1, jumlah rata-rata kualitas audit adalah 0,2870, nilai minimum 0 , nilai maksimum 0,73 dengan standar deviasi 0,17328 .

Tenor kantor akuntan publik yang diukur dari lamanya tahun pemberian jasa audit oleh kantor akuntan publik pada hasil pengujian statistik deskriptif menunjukkan jumlah rata-rata tenor kantor akuntan publik adalah 2,5505, nilai minimum 1,00, nilai maksimum 5,00 dengan standar deviasi 1,37871. Berdasarkan hasil pengujian tersebut dapat dikatakan bahwa pergantian kantor akuntan publik oleh perusahaan di industri manufaktur cukup sering.

Variabel ukuran kantor akuntan publik (KAP) yang menggunakan variabel dummy, pengujian dilakukan secara terpisah. Variabel ukuran KAP dilihat dari dua kategori, termasuk dalam KAP dengan pendapatan sama dengan atau di atas Rp 100 miliar setahun atau KAP dengan pendapatan di bawah Rp 100 miliar setahun.

Demikian halnya dengan variabel spesialisasi kantor akuntan publik (KAP) yang menggunakan variabel dummy. Variabel spesialisasi KAP dilihat dari dua kategori, termasuk dalam KAP yang menguasai pangsa pasar berupa pendapatan sebesar atau di atas $10 \%$ atau KAP dengan penguasaan pangsa pasar berupa pendapatan di bawah $10 \%$.

Berikut hasil pengujian statistik deskriptif yang telah dilakukan.

Tabel 2 Hasil Pengujian Statistik Deskriptif Variabel Skala Dummy

(Sumber: hasil olah data)

Ukuran KAP

\begin{tabular}{|c|c|c|c|c|}
\hline & Frequency & Percent & $\begin{array}{c}\text { Valid } \\
\text { Percent }\end{array}$ & $\begin{array}{c}\text { Cumulative } \\
\text { Percent }\end{array}$ \\
\hline Valid .00 & 259 & 53.4 & 53.4 & 53.4 \\
\hline 1.00 & 226 & 46.6 & 46.6 & 100.0 \\
\hline Total & 485 & 100.0 & 100.0 & \\
\hline
\end{tabular}


Keterangan :

0 : KAP kecil

1 : KAP besar

\begin{tabular}{|c|c|c|c|c|}
\hline \multicolumn{5}{|c|}{ Spesialisasi KAP } \\
\hline & Frequency & Percent & $\begin{array}{c}\text { Valid } \\
\text { Percent }\end{array}$ & $\begin{array}{c}\text { Cumulative } \\
\text { Percent }\end{array}$ \\
\hline Valid .00 & 301 & 62.1 & 62.1 & 62.1 \\
\hline 1.00 & 184 & 37.9 & 37.9 & 100.0 \\
\hline Total & 485 & 100.0 & 100.0 & \\
\hline
\end{tabular}

Keterangan :

0 : KAP non spesialis

1 : KAP spesialis

Berdasarkan tabel 2, terdapat KAP kecil sebanyak 259 dan KAP besar sebanyak 226. Sementara itu, jumlah KAP non spesialis sebanyak 301 dan KAP spesialis sebanyak 184.

Berdasarkan hasil uji normalitas dengan metode Kolmogorov-Smirnov, histogram dan plot (P-P Plot), maka dapat disimpulkan bahwa distribusi data adalah normal.

Pengujian multikolonieritas bertujuan untuk mengetahui ada tidaknya hubungan antar variabel-variabel independen. Sebuah model regresi yang baik seharusnya tidak mengandung korelasi diantara variabel-variabel independen tersebut. Untuk mengetahui ada tidaknya multikolonieritas dilihat dari Tolerance Value dan Variance Inflation Factor (VIF).

Berdasarkan hasil pengujian multikolonieritas menunjukan semua variabel-variabel independen memiliki nilai Variance Inflation Factor (VIF) kurang dari 10 yaitu: Tenor KAP $(1,137)$; Ukuran KAP $(3,475)$; dan Spesialisasi KAP $(3,560)$.

Berdasarkan hasil pengujian multikolonieritas juga menunjukan semua variabelvariabel independen memiliki nilai Tolerance Value lebih dari 0,1 yaitu : Tenor KAP $(0,879)$; Ukuran $\operatorname{KAP}(0,288)$; dan Spesialisasi KAP $(0,281)$.

Hasil pengujian multikolonieritas, menggambarkan tidak adanya hubungan antar variabel independen dengan nilai VIF $<10$ dan Tolerance $>0,1$. Dapat disimpulkan bahwa model regresi penelitian tersebut tidak mengalami multikolinearitas.

Hasil pengujian heteroskedasitas menunjukkan titik-titik scatterplot tersebar rata dan tidak membentuk pola tertentu. Hal ini berarti pada setiap prediksi, nilai residu memiliki variasi residu yang sama. Maka, dapat disimpulkan bahwa model regresi penelitian ini bebas dari heteroskedasitas.

Dalam penelitian ini untuk mendetekdi ada tidaknya autokorelasi dengan menggunakan uji Durbin-Watson.

Berdasarkan hasil uji autokorelasi pada tabel 4.6, menunjukan nilai Durbin-Watson (DW) sebesar 0,000, masih ada di kisaran nilai $-2 \leq \mathrm{DW} \leq 2$ sehingga model penelitian tidak terjadi autokorelasi.

Uji $\mathrm{F}$ ini bertujuan untuk mengetahui apakah variabel-variabel independen secara bersama-sama (simultan) mempengaruhi variabel dependen. Berikut merupakan hasil pengujian hipotesis simultan (uji F): 
Tabel 3 Hasil Uji F

(Sumber: hasil olah data)

ANOVA $^{\mathrm{a}}$

\begin{tabular}{|ll|r|r|r|r|r|}
\hline \multicolumn{2}{|l|}{ Model } & \multicolumn{1}{|c|}{$\begin{array}{c}\text { Sum of } \\
\text { Squares }\end{array}$} & \multicolumn{1}{c|}{ df } & $\begin{array}{c}\text { Mean } \\
\text { Square }\end{array}$ & \multicolumn{1}{c|}{ F } & \multicolumn{1}{c|}{ Sig. } \\
\hline 1 & Regression & .541 & 5 & .108 & .297 & $.915^{\mathrm{b}}$ \\
& Residual & 174.704 & 479 & .365 & & \\
& Total & 175.245 & 484 & & & \\
\hline 2 & Regression & 41.232 & 8 & 5.154 & 18.307 & $.000^{\mathrm{c}}$ \\
& Residual & 134.013 & 476 & .282 & & \\
& Total & 175.245 & 484 & & & \\
\hline
\end{tabular}

a. Dependent Variable: Zscore: Kualitas Audit

b. Predictors: (Constant), CFO, Size, Growth, Leverage, Loss

c. Predictors: (Constant), CFO, Size, Growth, Leverage, Loss, Zscore: Tenor KAP, Zscore: Ukuran KAP, Zscore: Spesialisasi KAP

Tabel 3 menunjukkan bahwa $\mathrm{F}$ hitung (Model 2) adalah 18,307 dengan tingkat signifikansi 0,000. Karena nilai probabilitas adalah 0,000 lebih kecil dari 0,05, maka model regresi bisa dipakai untuk memprediksi Zscore (Kualitas Audit). Atau bisa dikatakan Zscore:Tenor KAP (tenor KAP), Zscore: Ukuran KAP (ukuran KAP), Zscore: Spesialisasi KAP (Spesialisasi KAP), dikendalikan dengan Zscore:CFO (Operating Cash Flow perusahaan), Zscore: Size (ukuran perusahaan), Zscore: Growth (pertumbuhan perusahaan), Zscore:Leverage (leverage perusahaan), Zscore: Loss (kerugian perusahaan), secara bersama-sama berpengaruh terhadap Zscore (Kualitas Audit).

Berikut merupakan hasil pengujian hipotesis simultan (uji t):

Tabel 4 Hasil Uji T

(Sumber: hasil olah data)

Coefficients $^{\text {a }}$

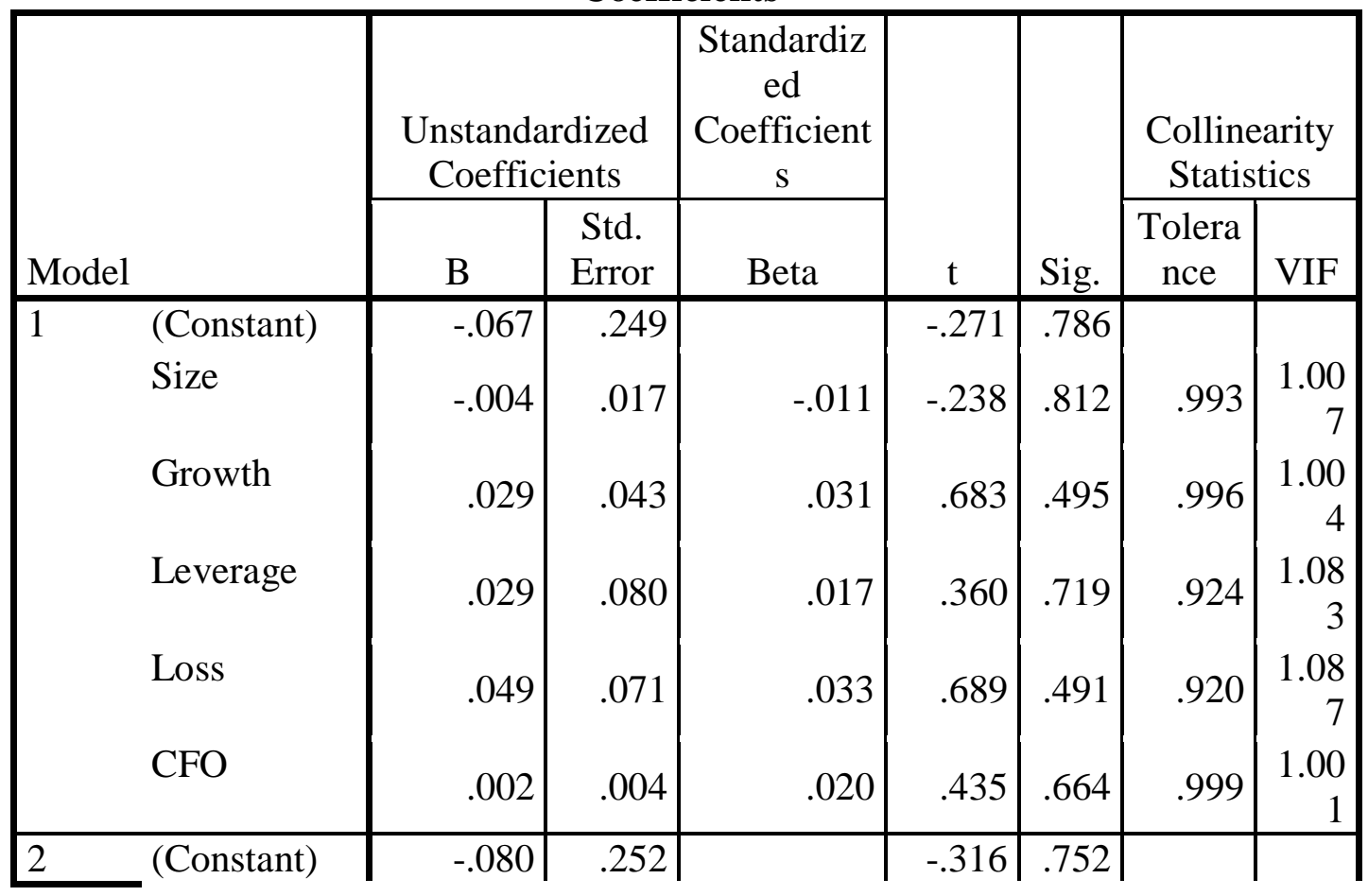




\begin{tabular}{|c|c|c|c|c|c|c|c|}
\hline Size & -.001 & .017 & -.002 & -.051 & .960 & .715 & $\begin{array}{r}1.39 \\
9\end{array}$ \\
\hline Growth & -.014 & .038 & -.015 & -.362 & .718 & .986 & 1.01 \\
\hline Leverage & -.042 & .071 & -.025 & -.594 & .553 & .901 & $\begin{array}{r}1.11 \\
0\end{array}$ \\
\hline Loss & .075 & .062 & .050 & 1.203 & .230 & .918 & $\begin{array}{r}1.08 \\
9\end{array}$ \\
\hline $\mathrm{CFO}$ & .000 & .003 & .002 & .047 & .962 & .996 & $\begin{array}{r}1.00 \\
4\end{array}$ \\
\hline $\begin{array}{l}\text { Zscore: } \\
\text { Tenor KAP }\end{array}$ & -.298 & .026 & -.493 & 11.543 & .000 & .879 & $\begin{array}{r}1.13 \\
7\end{array}$ \\
\hline $\begin{array}{l}\text { Zscore: } \\
\text { Ukuran } \\
\text { KAP }\end{array}$ & -.038 & .045 & -.064 & -.859 & .391 & .288 & $\begin{array}{r}3.47 \\
5\end{array}$ \\
\hline $\begin{array}{l}\text { Zscore: } \\
\text { Spesialisasi } \\
\text { KAP }\end{array}$ & .148 & .045 & .247 & 3.269 & .001 & .281 & $\begin{array}{r}3.56 \\
0\end{array}$ \\
\hline
\end{tabular}

a. Dependent Variable: Zscore: Kualitas Audit

Tabel 4 menunjukkan hasil pengujian secara parsial pengaruh masing-masing variabel independen terhadap variabel dependen, dikendalikan dengan ukuran perusahaan, pertumbuhan perusahaan, leverage, kerugian dan arus kas operasi.

Berikut hasil pengujian secara parsial:

a. Pengaruh Tenor Kantor Akuntan Publik terhadap Kualitas Audit

Berdasarkan hasil uji t yang disajikan menunjukkan bahwa nilai signifikansi variabel tenor kantor akuntan publik adalah sebesar 0,000 yang bernilai lebih kecil dari 0,05. Hal ini menunjukkan bahwa tenor kantor akuntan publik berpengaruh signifikan terhadap kualitas audit.

b. Pengaruh Ukuran Kantor Akuntan Publik terhadap Kualitas Audit

Berdasarkan hasil uji t yang disajikan menunjukkan bahwa nilai signifikansi variabel ukuran kantor akuntan publik adalah sebesar 0,391 yang bernilai lebih besar dari 0,05. Hal ini menunjukkan bahwa ukuran kantor akuntan publik tidak berpengaruh signifikan terhadap kualitas audit.

c. Pengaruh Spesialisasi Kantor Akuntan Publik terhadap Kualitas Audit

Berdasarkan hasil uji t yang disajikan menunjukkan bahwa nilai signifikansi variabel spesialisasi kantor akuntan publik adalah sebesar 0,001 yang bernilai lebih kecil dari 0,05. Hal ini menunjukkan bahwa spesialisasi kantor akuntan publik berpengaruh signifikan terhadap kualitas audit.

Hasil pengujian koefisien determinasi menunjukkan nilai koefisien determinasi, angka $\mathrm{R}^{2}$ adalah 0,235 (adalah pengkuadratan dari koefisien korelasi, atau 0,485 x 0,485 $=0,235) \cdot \mathrm{R}^{2}$ bisa disebut koefisien determinasi, yang dalam hal ini berarti $23,5 \%$ dari variabel kualitas audit bisa dijelaskan oleh variabel-variabel independen yang diteliti. $\mathrm{R}^{2}$ berkisar pada angka 0 sampai 1 , dengan catatan semakin kecil angka $\mathrm{R}^{2}$, semakin lemah hubungan kedua variabel. 


\section{Diskusi}

Berdasarkan hasil dari pengujian hipotesis bahwa tenor kantor akuntan publik berpengaruh signifikan dan positif terhadap kualitas audit. Hasil penelitian ini sejalan dengan penelitian yang dilakukan oleh Sisylia Nata (2010) dimana audit firm tenure yang lebih panjang, manajemen laba akan menurun. Dalam penelitian Chih Ying Chen, Chan Jane Lin and Yu Chen Lin (2004), tidak terdapat bukti bahwa kualitas laba menurun sejalan dengan audit firm tenure. Hal ini disebabkan oleh makin bertambahnya pemahaman auditor atas perusahaan yang diaudit sesuai dengan lamanya audit.

Berdasarkan hasil dari pengujian hipotesis bahwa ukuran kantor akuntan publik tidak berpengaruh signifikan terhadap kualitas audit. Hasil penelitian ini sejalan dengan penelitian yang dilakukan oleh Antonius Herusetya (2009) yang menyatakan bahwa tidak terdapat perbedaan kualitas laba antara perusahaan yang diaudit auditor Big 4 dan auditor non-Big 4. Namun penelitian ini tidak sejalan dengan penelitian yang dilakukan oleh Arie Wibowo dan Hilda Rossieta Ph.D (2009) yang menyatakan bahwa ukuran KAP yang semakin besar akan meningkatkan kualitas audit.

Berdasarkan hasil dari pengujian hipotesis bahwa spesialisasi kantor akuntan publik berpengaruh signifikan terhadap kualitas audit. Hasil penelitian ini sejalan dengan penelitian yang dilakukan oleh Fitriany (2015) dimana terdapat hubungan negatif antara spesialisasi kantor akuntan publik terhadap kualitas audit. Hal ini mungkin disebabkan kurangnya independensi auditor spesialis. Spesialis mencerminkan kompetensi dan independensi. Hal ini sesuai dengan penelitian Kallapur (2008) dimana semakin tinggi market concentration, semakin rendah kualitas audit. Untuk mempertahankan market share, ada kemungkinan KAP spesialis mengorbankan independensi untuk mempertahankan kliennya. Artinya spesialisasi auditor tidak cukup mengimbangi pengaruh dari kurangnya independensi sehingga menyebabkan kualitas audit menurun. Hasil penelitian ini bertentangan dengan penelitian yang dilakukan Balsam (2003) dimana klien-klien yang diaudit auditor spesialis memiliki kualitas laba yang lebih tinggi dari klien-klien yang diaudit oleh auditor.

\section{KESIMPULAN DAN SARAN}

Berdasarkan hasil pengujian hipotesis yang dilakukan dapat disimpulkan bahwa tenor kantor akuntan publik mempunyai nilai signifikansi sebesar 0,000. Hal ini menunjukkan bahwa tenor kantor akuntan publik berpengaruh signifikan terhadap kualitas audit sehingga dapat disimpulkan bahwa $\mathrm{H}_{1}$ diterima. Terdapat hubungan yang positif antara tenor kantor akuntan publik dan kualitas audit. Hasil penelitian ini sejalan dengan penelitian yang dilakukan oleh Sisylia Nata (2010) dimana audit firm tenure yang lebih panjang, manajemen laba akan menurun. Hal ini kemungkinan disebabkan oleh makin bertambahnya pemahaman auditor atas perusahaan yang diaudit sesuai dengan lamanya audit.

Ukuran kantor akuntan publik memiliki signifikansi sebesar 0,391. Hal ini menunjukkan bahwa ukuran kantor akuntan publik tidak berpengaruh signifikan terhadap kualitas audit. Hasil penelitian ini sejalan dengan penelitian yang dilakukan oleh Antonius Herusetya (2009) yang menyatakan bahwa tidak terdapat perbedaan kualitas laba antara perusahaan yang diaudit auditor Big 4 dan auditor non-Big 4 .

Spesialisasi kantor akuntan publik memiliki signifikansi sebesar 0,001. Hal ini menunjukkan bahwa spesialisasi kantor akuntan publik berpengaruh signifikan terhadap kualitas audit. Hasil penelitian ini sejalan dengan penelitian yang dilakukan oleh Fitriany (2015) dimana terdapat hubungan negatif antara spesialisasi kantor akuntan publik terhadap kualitas audit. Hal ini mungkin disebabkan kurangnya independensi auditor spesialis. Spesialis mencerminkan kompetensi dan independensi. Hal ini sesuai dengan 
penelitian Kallapur (2008) dimana semakin tinggi market concentration, semakin rendah kualitas audit. Untuk mempertahankan market share, ada kemungkinan KAP spesialis mengorbankan independensi untuk mempertahankan kliennya.

Penelitian ini masih jauh dari sempurna karena memiliki beberapa keterbatasan. Informasi yang dipakai dalam penelitian ini hanya terbatas dengan menggunakan laporan keuangan perusahaan saja.

Dalam penelitian ini menggunakan discretionary accrual sebagai proksi untuk kualitas audit. Penelitian selanjutnya dapat menggunakan proksi lain untuk kualitas audit.

Penelitian saat ini dilakukan untuk industri manufaktur, disarankan untuk penelitian selanjutnya dapat dilakukan untuk industri lainnya untuk perusahaan-perusahaan yang tercatat di Bursa Efek Indonesia.

\section{REFERENSI}

Arens.Alvin A, Randal J. Elder and Mark S. Beasley (2008). Auditing and Assurance Services, An Integrated Approach.

Balsam.Steven, Jagan Krishnan, and Joon S. Yang (2003). Auditor Industry Specialization and Earnings Quality

Cameran.Mara, Annalisa Prencipe, and Marco Trombetta (2014). Mandatory Audit Firm Rotation and Audit Quality

Chen.Chih Ying, Chan Jane Lin and Yu Chen Lin (2004). Audit Partner Tenure, Audit Firm Tenure, and Discretionary Accruals: Does Long Auditor Tenure Impair Earnings Quality?

Choudhury.Fayez (2016). Mandatory Audit Firm Rotation-Are We Going 'Round in Circles?

Davis.Larry R, Billy Soo and Greg Trompeter (2000). Auditor Tenure, Auditor Independence and Earnings Management

DeAngelo.Linda Elizabeth (1981). Auditor Size and Audit Quality

Dechow (1994). Accounting earnings and cash-flows as measures of firm performance: the role of accounting accruals.

Dechow, Patricia M, Amy P. Hutton, Jung Hoon Kim and Richard G. Sloan (2011). Detecting Earnings Management: A New Approach

Fitriany, Sidharta Utama, Dwi Martani and Hilda Rosietta (2015). Pengaruh Tenure, Rotasi dan Spesialisasi Kantor Akuntan Publik (KAP) Terhadap Kualitas Audit: Perbandingan Sebelum dan Sesudah Regulasi Rotasi KAP di Indonesia

Fuerman.Ross D. and Michael Kraten (2008). Intra-Non-Big 4 Auditor Quality

Gavious.Elanit (2006). Alternative Perspectives to Deal with Auditors' Agency Problem

Ghozali.Imam (2013). Aplikasi Analisis Multivariate dengan Program IBM SPSS 21

Herusetya.Antonius (2009). Pengaruh Ukuran Auditor dan Spesialisasi Auditor Terhadap Kualitas Laba

IAASB (2013). A Framework for Audit Quality

Jensen. Michael C and William H. Meckling (1976). Theory of the Firm: Managerial Behavior, Agency Costs and Ownership Structure

Jones.Jennifer J (1991). Earnings Management During Import Relief Investigations

Kadir (2015). Statistika Terapan: Konsep, Contoh dan Analisis Data dengan Program SPSS/Lisrel dalam Penelitian.

Kallapur.Sanjay (2008). Audit Market Competition and Audit Quality.

Lobo.Gerald J and Jian Zhou (2006). Did Conservatism in Financial Reporting Increase after Sarbanes-Oxley Act? Initial Evidence.

Meza.Miguel Minutti (2010). Does Auditor Industry Specialization Improve Audit Quality? Evidence from Comparable Client. 
Nata.Sisylia (2010). Audit Partner Tenure dan Audit Firm Tenure Terhadap Earnings Management Pada Perusahaan Manufaktur.

PT Bursa Efek Indonesia (2016). IDX Fact Book 2016

Public Company Accounting Oversight Board (2013). Discussion-Audit Quality Indicators

Maria R.L.A (2016). Audit Firm Rotation and Audit Quality

Sarwono, Jonathan (2013). 12 Jurus Ampuh SPSS untuk Riset Skripsi.

Sarwono, Jonathan (2006). Metode Penelitian Kuantitatif dan Kualitatif.

Siregar.Sylvia Veronica, Fitriany, Arie Wibowo dan Viska Anggraita (2011). Rotasi dan Kualitas Audit: Evaluasi atas Kebijakan Menteri Keuangan KMK No. 423/KMK.6/2002 tentang Jasa Akuntan Publik

Siregar.Sylvia Veronica, Fitriany Amarullah, Arie Wibowo \& Viska Anggraita (2012). Audit Tenure, Auditor Rotation, and Audit Quality: The Case of Indonesia

Tuanakotta.Theodorus M (2011). Berpikir Kritis Dalam Auditing

Wibowo.Arie dan Hilda Rossieta Ph.D (2009). Faktor-faktor Determinasi Kualitas AuditSuatu Studi dengan Pendekatan Earnings Surprise Benchmark 